\title{
非小細胞肺癌に対する術後補助化学療法
}

\author{
豊岡伸一
}

岡山大学大学院医歯薬学総合研究科 呼吸器 - 乳腺内分泌外科学

キーワード：非小細胞肺癌, 外科治療, 術後補助化学療法

\section{Adjuvant chemotherapy for non small-cell lung cancer}

\section{Shinichi Toyooka}

Department of General Thoracic Surgery and Breast and Endocrinological Surgery, Okayama University Graduate School of Medicine, Dentistry and Pharmaceutical Sciences

\section{緒言}

肺癌は，本邦さらには世界的に癌死の死因第一位で ある．肺癌に対する根治的な治療は現在のところ外科 切除が望ましく, 特に非小細胞肺癌の臨床病期 stage I - II 期と一部の stage III期の症例では外科手術が基 本となり, その後, 病理病期によって補助療法を行う ことがある。術後補助療法の主体は補助化学療法であ るが, 本邦では病理病期 I A 期と I B 期の肺腺癌に対し て Tegafur/Uracil が推奨されている。また病理病期 II - III期の非小細胞肺癌については，主に欧米のデータ をもとにシスプラチン併用療法が術後補助療法として 推奨されている. 今後であるが, 現在, 進行非小細胞 肺癌に対し分子標的薬, 免疫チェックポイント阻害薬 などの新しい薬剤の効果が示されており, 術後補助療 法としても導入される可能性がある。本稿では非小細 胞肺癌の術後補助化学療法についての現状と今後につ いて述べる。

\section{平成30年 1 月 21 日受理}

干700-8558 岡山市北区鹿田町 2-5-1

電話：086-235-7265 FAX : 086-235-7268

E-mail : toyooka@md.okayama-u.ac.jp

\section{非小細胞肺癌に対する術後補助化学療法の歴史とエビ デンス}

肺癌には大別して非小細胞肺癌と小細胞肺癌に分け られる。肺癌の根治を目指すためには，早期発見と外 科治療による根治手術が重要であるが，根治手術後の 再発の有無は予後を左右する大きな因子である。その ため, 特に切除可能な症例が比較的多い非小細胞肺癌 において外科治療後の補助化学療法が注目されてき た。図 1 に現在まで行われてきた，非小細胞肺癌に対 する術後補助化学療法の代表的な臨床試験を示す。海 外で行われたシスプラチン (CDDP) 併用療法の有用 性を検討する臨床試験が積極的に行われ有用性を示す ことができない試験もあったが (表 1$)^{1-5)}$ ，メタアナ リシスの結果も踏まえ最終的に CDDP 併用療法が手 術単独と比較して有意に予後を改善することが示され た6). 中でも VNR + CDDP 併用療法が中心的なレジメ ンとして使用されている。海外で行われた主なプラチ ナ併用の術後化学療法について表に示した（表 1 ). 特 に International Adjuvant Lung Cancer Trial (IALT) 試験 ${ }^{2)}$, JBR.10試験 ${ }^{4}$, Adjuvant Navelbine International Trialist Association（ANITA）試験5)において CDDP

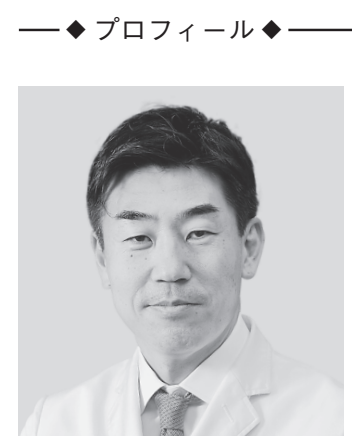

平成 6 年 4 月 岡山大学医学部 第二外科

平成 6 年 9 月 三豊総合病院 外科研修医

平成13年 3 月 岡山大学大学院医学研究科修了

平成11年 9 月

米国テキサス大学サウスウエスタンメディカルセンターハマン癌センター

ポストドクトラルフェロー

平成14年 7 月 岡山大学医学部附属病院 第二外科 医員

平成14年 9 月 香川県立中央病院 外科医員

平成15年 9 月 国立がんセンター東病院 胸部外科

平成16年 5 月 岡山大学医学部附属病院 呼吸器外科 医員

平成16年10月岡山大学医学部・歯学部附属病院 呼吸器外科 助手

平成19年 4 月 岡山大学医学部・歯学部附属病院 呼吸器外科 助教

平成23年 4 月 岡山大学病院 呼吸器外科 講師

平成25年 4 月 岡山大学大学院医歯薬学総合研究科 臨床遺伝子医療学 教授

平成29年 6 月 岡山大学大学院医歯薬学総合研究科 呼吸器・乳腺内分泌外科学 教授 


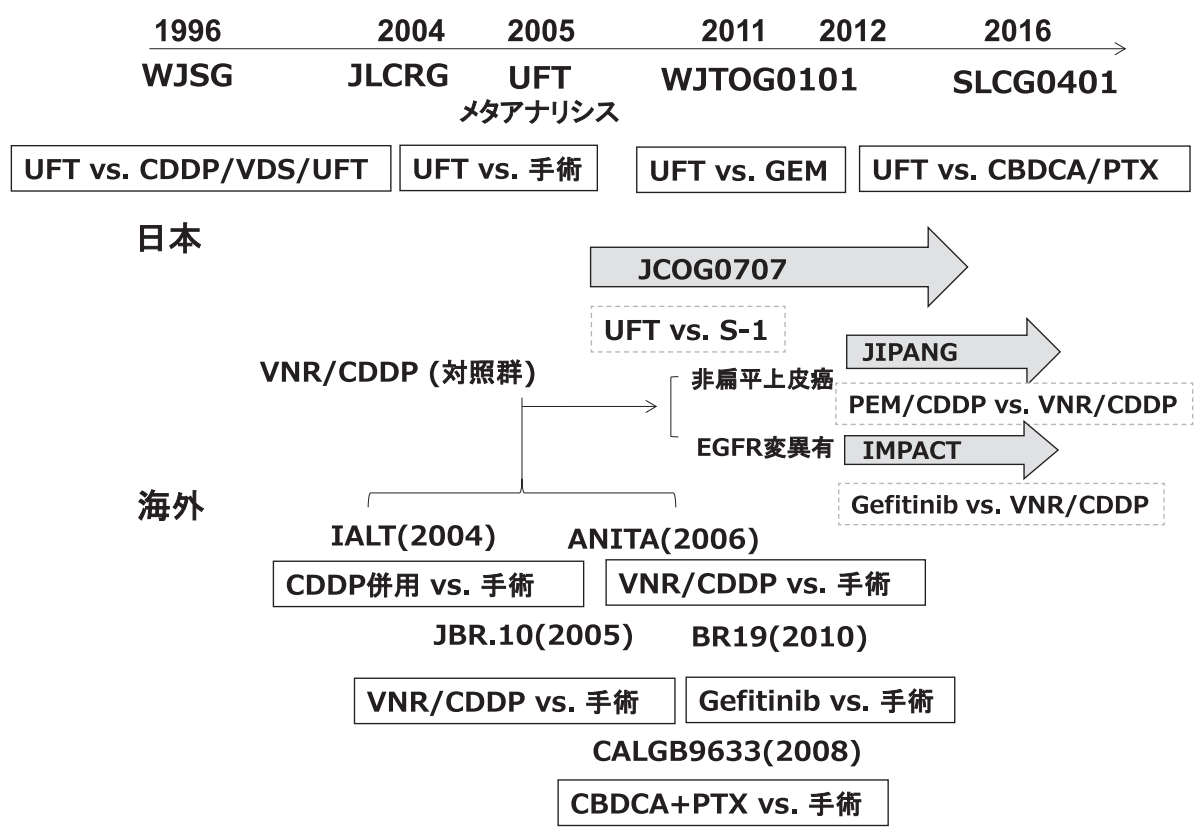

図 1 非小細胞肺癌術後補助化学療法の臨床試験

UFT, Tegafur/Uracil ; CDDP, シスプラチン；VDS, ビンデシン；MMC，マイトマイシンC ; EPT, エトポシド ; VNR, ビノレル ビン；VBL, ビンブラスチン；CBDCA, カルボプラチン；PTX, パクリタキセル ; GEM, ジェムシタビン ; WJSG, West Japan Study Group ; JLCRG, Japan Lung Cancer Research Group ; WJTOG, West Japan Thoracic Oncology Group ; SLCG, Setouchi Lung Cancer Study Group ; JCOG, Japan Clinical Oncology Group ; JIPANG, Japan Intergroup Trial of Pemetrexed Adjuvant Chemotherapy for completely resected Non-squamous Non-small cell lung cancer; IMPACT, Iressa for Mutation Positive against Adjuvant Chemotherapy Trial ; IALT, International Adjuvant Lung Cancer Trial ; Adjuvant Navelbine International Trialist Association, ANITA ; Cancer and Leukemia Group B ; GALGB.

表 1 海外におけるプラチナ併用術後補助化学療法

\begin{tabular}{|c|c|c|c|c|c|c|}
\hline 試験名 & ALPI & IALT & BLT & JBR.10 & ANITA & CALGB9633 \\
\hline 報告年 & 2003 & 2004 & 2004 & 2005 & 2006 & 2008 \\
\hline 対象病期 & I IIIA & I IIIA & $\mathrm{I} \sim \mathrm{III}$ & IB, II & IB IIIA & IB \\
\hline 症例数 & 1,209 & 1,867 & 381 & 482 & 840 & 344 \\
\hline 治療内容 & $\begin{array}{l}\text { CDDP+VDS+ } \\
\text { MMC }\end{array}$ & $\begin{array}{l}\text { +ETP(57\%) } \\
\text { +VNR(27\%) } \\
\text { +VBL(11\%) } \\
\text { +VDS(6\%) }\end{array}$ & $\begin{array}{c}\text { CDDP+MMC+ } \\
\text { IFM/VBL } \\
\text { CDDP+VDS/VNR }\end{array}$ & $\mathrm{CDDP}+\mathrm{VNR}$ & $\mathrm{CDDP}+\mathrm{VNR}$ & CBDCA+PTX \\
\hline $\begin{array}{c}\text { 観察期間 } \\
\text { 中央値(月) }\end{array}$ & 64.5 & 56 & 34.6 & 5.1年 & 76 & 74 \\
\hline $\begin{array}{c}\mathrm{HR} \\
{[95 \% \mathrm{CI}]}\end{array}$ & $\begin{array}{c}0.96 \\
{[0.81-1.13]}\end{array}$ & $\begin{array}{c}0.86 \\
{[0.76-0.98]}\end{array}$ & $\begin{array}{c}1.02 \\
{[0.77-1.35]}\end{array}$ & $\begin{array}{c}0.69 \\
{[0.52-0.91]}\end{array}$ & $\begin{array}{c}0.80 \\
{[0.66-0.96]}\end{array}$ & $\begin{array}{c}0.83 \\
90 \% \mathrm{CI} \\
{[0.64-1.08]}\end{array}$ \\
\hline p値 & 0.589 & $<0.03$ & 0.90 & 0.009 & 0.017 & 0.12 \\
\hline 5生の差(\%) & 3 & 4.1 & $-2(2 y)$ & 15 & 12.9 & 2 \\
\hline
\end{tabular}

CDDP，シスプラチン; VDS，ビンデシン；MMC，マイトマイシンC ; EPT, エトポシド ; VNR，ビノレルビン;

VBL, ビンブラスチン; CBDCA, カルボプラチン; PTX, パクリタキセル;HR, hazard ratio; CI, confidence interval

併用の術後補助療法の有用性が証明された. CDDPを 使用した 5 つの補助化学療法でのメタアナリシスにお いても CDDP 併用による術後補助化学療法は 5 年生 存率を $5.4 \%$ 改善することが示された 7 ). 中でもサブセ ット解析としてビノレルビン $(\mathrm{VNR})+\mathrm{CDDP}$ 併用療
法に限った解析では全体で 5 年生存率を $8.9 \%$ 改善し ていた7)。さらに, 病期毎の解析では病理病期 I 期で は予後は改善されなかったが, 病理病期 II - III期では10 $\%$ 以上の改善を認めた ${ }^{7)}$. なお, カルボプラチン (CBDCA) は CDDP と同様，プラチナ製剤であり， 
CBDCA とパクリタキセル（PTX）による術後補助療 法の有用性が病理病期 IB 期の非小細胞肺癌において 検討されたが, 外科手術単独と比較し生存延長効果は 認められなかった ${ }^{8)}$. 以上のことから海外のデータが 主であるが, 病理病期 II-III 期の非小細胞肺癌に対して $\mathrm{VNR}+\mathrm{CDDP}$ 併用による術後補助療法が標準治療と して考えられている.

一方, 本邦では経口薬である Tegafur/Uracil (UFT) について有効性を検証する臨床試験が行われてきた。 和田らの West Japan Study Group (西日本肺癌手術補 助化学療法研究会, WJSG）により, 病理病期 I - II 期 を対象に, CDDP + VDS + UFT 群, UFT 群, 手術単 独の 3 群についての比較試験が行われ， 5 年生存率で UFT 群は $64 \%$ と手術単独群の $49 \%$ と比し, 有意に良好 であった ${ }^{9)}$.また, Japan Lung Cancer Research Group (日本肺癌術後補助化学療法研究会, JLCRG) におい て病理病期 I 期の肺腺癌に対する UFT の効果を検討 する第正相試験が行われ，全体では $3 \%(85 \% \rightarrow 88 \%)$, stage IB 期 $(\mathrm{T}>3 \mathrm{~cm})$ においては11\%（74\% $\rightarrow 85 \%)$ の予後延長効果が認められた ${ }^{10)}$.さらに2,003例による メ夕解析の結果では全体で $5 \%(77 \% \rightarrow 82 \%)$ の 5 年 生存率の改善を認め, UFT の有効性が確認された ${ }^{11)}$. ただこれらの結果の元になった症例の組織型は, 肺 腺癌1,679例, 扁平上皮癌299例, その他25例であり非 腺癌の症例は少数であることから非腺癌においては有 用性が確立されていないと考えられている ${ }^{11}$. 2010年 から運用を開始した第 7 版の TNM 分類ではT 1 が細 分化され, $2 \mathrm{~cm}$ 以下の $\mathrm{T} 1 \mathrm{a}$ と $2 \mathrm{~cm}$ から $3 \mathrm{~cm}$ の $1 \mathrm{~b}$ に 分類された。この第 7 版に基づいて腫瘍径が $3 \mathrm{~cm}$ 以下 の病理病期 I A 期に限ったメタアナリシスでは T $1 \mathrm{a}$ ではUFTの有効性はなかったが, T1bでオぺ単独群 と比較し UFT 群が有意に生存を延長した ${ }^{12}$. この結 果により, 病理病期 IA 期の非小細胞肺癌症例, 特に 腫瘍径が $2 \mathrm{~cm}$ より大きく, $3 \mathrm{~cm}$ 以下の症例に対し UFT が有効であることが示された。その他, UFTを含んだ 非小細胞肺癌術後補助療法の第三相試験として病理病 期 IB-IIA 期を対象としたUFTとジェムシタビンの 比較試験 [西日本胸部腫瘍臨床研究機構 (WJTOG) 0101 試験) ], 同じ対象群に対するUFTと PTX+ CBDCA 併用療法の比較試験 [瀬戸内肺癌研究会

（SLCG）0401試験）が終了しているがまだ論文発表 はされていない. なお, Japan Clinical Oncology Study Group（日本臨床腫瘍研究グループ, JCOG）による病
理病期 IA 期（T1bのみ）およびIB期に対する UFT と Tegafur/Gimeracil/Oteracil（TS-1）の第三相試験 （JCOG0707試験）が症例の集積を終えている.

また，2017年から，TNM 分類は第 8 版となってお り，T因子はさらに細分化され腫瘍の全体径ではなく 腫瘍の浸潤性増殖を示す部分の径が考慮されることに なっている. TNM 分類は複雑化しているが, あくま で今までのエビデンスの確立は臨床試験が設定された 時の病期のものであり, この事実を考慮して術後補助 療法を考える必要がある。

\section{非小細胞肺癌に対する術後補助化学療法の今後}

以上のように非小細胞肺癌術後の術後補助化学療法 の有用性が臨床試験により確立されてきた。いうまで もないが, 術後補助化学療法が効果を示す可能性があ る病変はBulky な腫瘍ではなく微小転移巣というこ とになる。また，手術により根治している症例も早期 であればあるほど割合が高いため，強力すぎる化学療 法が施行された場合，治療関連死などの有害事象によ り治療自体が生存に負の影響を与える可能性がある。 CDDP 併用の術後補助療法が病理病期 II - II 期では有 用であったが，病理病期 I 期では有用性を示していな いのはこのような理由が一因であろう。そのためには 術後補助化学療法を行う症例選択と治療薬選択が重要 となってくる．前者は，微小転移の存在を術後に見つ けることが鍵になるが，例えば，完全切除を行っても 微小病変が残っている場合, 癌由来の cell free DNA （cfDNA）を検出することにより症例選択ができる可 能性がある. 現在, cfDNA を検出するリキッドバイオ プシーの技術が向上しており，術後のスクリーニング としての臨床応用が望まれる。後者の治療薬選択につ いては，がんのゲノム変異に基づく薬剤の選択などが 一つの方向性であり，本邦ではその一例としてヒト上 皮成長因子受容体遺伝子（EGFR）の変異症例に対し てEGFR チロシンキナーゼ阻害薬であるゲフィチニ ブと VNR + CDDP 併用療法の第三相試験が行われて いる (Iressa for Mutation Positive against Adjuvant Chemotherapy Trial, IMPACT 試験)。なお, Goss ら により行われた $E G F R$ 遺伝子変異による症例選択を 行わないゲフィチニブと手術単独の比較試験 (BR19試 験)ではゲフィチニブの有用性は認められなかった ${ }^{13)}$. また, 組織型による症例選択の例として, 非扁平上皮 癌に対するペメトレキセド+CDDP 併用療法と VNR 
$+\mathrm{CDDP}$ 併用療法の臨床試験が実施されている (Japan Intergroup Trial of Pemetrexed Adjuvant Chemotherapy for completely resected Non-squamous Non-small cell lung cancer, JIPANG 試験).さらに, 最近では進行肺癌に PD-1 阻害剂など免疫チェックポ イント阻害薬の有用性が, 二次治療, 一次治療の両方 において示されている ${ }^{14,15)}$. 今後, 肺癌術後補助療法 における免疫チェックポイント阻害薬のエビデンスの 確立が待たれる。

\section{終わりに}

\section{上述のごとく肺癌の術後補助化学療法における課題} は，新しい技術や薬椷の登場によりむしろ増加してい る、ただ，これらの課題の解決は予後の改善に直結す るものであるため早急に取り組む必要がある。また， 高齢者に対する肺癌手術の機会も増えており, 高齢者 に対する安全かつ効果的な術後補助化学療法を開発し ていくことも重要であろう. 多角的な視点から課題を 解決し, 肺癌の治療成績の向上を目指すことが肝要で ある。

\section{文献}

1) Scagliotti GV, Fossati R, Torri V, Crino L, Giaccone G, et al. : Randomized study of adjuvant chemotherapy for completely resected stage I, II, or III A non-small-cell Lung cancer. J Natl Cancer Inst (2003) 95, 1453-1461.

2 ) Arriagada R, Bergman B, Dunant A, Le Chevalier T, Pignon JP, et al. : Cisplatin-based adjuvant chemotherapy in patients with completely resected non-small-cell lung cancer. N Engl J Med (2004) 350, 351-360.

3 ) Waller D, Peake MD, Stephens RJ, Gower NH, Milroy R, et al. : Chemotherapy for patients with non-small cell lung cancer : the surgical setting of the Big Lung Trial. Eur J Cardiothorac Surg (2004) 26, 173-182.

4 ) Winton T, Livingston R, Johnson D, Rigas J, Johnston M, et al. : Vinorelbine plus cisplatin vs. observation in resected non-small-cell lung cancer. N Engl J Med (2005) 352, 2589-2597.

5 ) Douillard JY, Rosell R, De Lena M, Carpagnano F, Ramlau $\mathrm{R}$, et al. : Adjuvant vinorelbine plus cisplatin versus observation in patients with completely resected stage IBIII A non-small-cell lung cancer (Adjuvant Navelbine International Trialist Association [ANITA]) : a randomised controlled trial. Lancet Oncol (2006) 7, 719-727.

6 ) Pignon JP, Tribodet H, Scagliotti GV, Douillard JY, Shepherd FA, et al. : Lung adjuvant cisplatin evaluation : a pooled analysis by the LACE Collaborative Group. J Clin Oncol (2008) 26, 3552-3559.

7 ) Douillard JY, Tribodet H, Aubert D, Shepherd FA, Rosell $\mathrm{R}$, et al. : Adjuvant cisplatin and vinorelbine for completely resected non-small cell lung cancer : subgroup analysis of the Lung Adjuvant Cisplatin Evaluation. J Thorac Oncol (2010) 5 , 220-228.

8 ) Strauss GM, Herndon JE, 2nd, Maddaus MA, Johnstone DW, Johnson EA, et al. : Adjuvant paclitaxel plus carboplatin compared with observation in stage IB non-small-cell lung cancer: CALGB 9633 with the Cancer and Leukemia Group B, Radiation Therapy Oncology Group, and North Central Cancer Treatment Group Study Groups. J Clin Oncol (2008) 26, 5043-5051.

9 ) Wada H, Hitomi S, Teramatsu T : Adjuvant chemotherapy after complete resection in non-small-cell lung cancer. West Japan Study Group for Lung Cancer Surgery. J Clin Oncol (1996) 14, 1048-1054.

10) Kato H, Ichinose $Y$, Ohta M, Hata E, Tsubota N, et al. : A randomized trial of adjuvant chemotherapy with uraciltegafur for adenocarcinoma of the lung. N Engl J Med (2004) 350, 1713-1721.

11) Hamada C, Tanaka F, Ohta M, Fujimura S, Kodama K, et al. : Meta-analysis of postoperative adjuvant chemotherapy with tegafur-uracil in non-small-cell lung cancer. J Clin Oncol (2005) 23, 4999-5006.

12) Hamada C, Tsuboi M, Ohta M, Fujimura S, Kodama K, et al. : Effect of postoperative adjuvant chemotherapy with tegafur-uracil on survival in patients with stage IA nonsmall cell lung cancer : an exploratory analysis from a meta-analysis of six randomized controlled trials. J Thorac Oncol (2009) 4, 1511-1516.

13) Goss GD, O'Callaghan C, Lorimer I, Tsao MS, Masters GA, et al. : Gefitinib versus placebo in completely resected nonsmall-cell lung cancer : results of the NCIC CTG BR19 study. J Clin Oncol (2013) 31, 3320-3326.

14) Brahmer J, Reckamp KL, Baas P, Crino L, Eberhardt WE, et al. Nivolumab versus Docetaxel in Advanced Squamous-Cell Non-Small-Cell Lung Cancer. N Engl J Med (2015) 373, 123-135.

15) Reck M, Rodriguez-Abreu D, Robinson AG, Hui R, Csoszi T, et al. : Pembrolizumab versus Chemotherapy for PD-L1Positive Non-Small-Cell Lung Cancer. N Engl J Med (2016) 375, 1823-1833. 